\title{
PENGARUH KECERDASAN EMOSIONAL DAN GAYA KEPEMIMPINAN DEMOKRATIS TERHADAP PERFORMANSI KEPALA RA PEREMPUAN DI KABUPATEN PATI
}

\author{
Kamto \\ STAI Pati \\ abusalmapati@gmail.com
}

\begin{abstract}
Abstrak
Penelitian ini bertujuan untuk mengetahuipengaruh kecerdasan emosional dan gaya kepemimpinan demokratis terhadap performansi kepala $R A$ perempuan di Kabupaten Pati. Populasi penelitian ini adalah seluruh kepala RA se-Kabupaten Pati yang berjumlah 221 orang dengan sampel 135 orang. Statistik uji yang digunakan adalah uji regresi ganda dengan bantuan softwareSPSS 17. Hasil penelitian ini menunjukkan bahwa 1) nilai korelasi (r) sebesar 0,188 yang menunjukkan adanya hubungan antara kecerdasan emosional dengan performansi kepala $R A$ perempuan 2) nilai korelasi (r) sebesar 0,206 menunjukkan adanya hubungan antara kepemimpinan demokratis dengan performansi kepala RA perempuan. 3) Kecerdasan emosional dan kepemimpinan demokratis secara bersama-sama atau simultan berpengaruh positif dan signifikan terhadap performansi kepala RA perempuan di Kabupaten Pati yang ditunjukkan dengan nilai $F$ test sebesar 5,356 dan nilai sig. pada 0,006. Hal ini berarti bahwa semakin baik kecerdasan emosional dan kepemimpinan demokratis maka akan diikuti peningkatan performansi kepala RA perempuan di Kabupaten Pati.
\end{abstract}

Kata Kunci: Kecerdasan emosional, Gaya Kepemimpinan demokratis dan performansi

\begin{abstract}
This study aims to menaganlisisi influence of emotional intelligence, and the democratic leadership style to the performance of the head of RA Raudlotul women in Pati regency. Respondents in this study is the head Rayang amounted to 221 people with a sample of 135 people. The analysis used is multiple regression with SPSS 17. Results and discussion shows that 1) The value of correlation (r) of 0.188 indicates the relationship between emotional intelligence and the performance of the head of RA female Raudlatul 2) The value of the correlation (r) of 0.206 indicates a relationship between the democratic leadership and the performance of the head of RA Raudlatul women. 3) Emotional intelligence and the democratic leadership together or simultaneous positive and significant impact on the performance of the head of $R A$ Raudlatul women in Pati regency that $F$ test value of 5.356 and sig. at 0.006. Emotional intelligence means the better and it will be followed democratic leadership performance improvement Raudlatul head Athfal women in Pati regency.
\end{abstract}

Keywords: Emotional Intelligence, Democratic Leadership Style, Performance 


\section{A. PENDAHULUAN}

Kepemimpinan dalam pendidikan menjadi sesuatu yang sangat unik. Kepemimpinan oleh banyak pakar, peneliti, pengamat, dan praktisi tetap dipandang sebagai misteri (Danim, 2012). Apalagi ketika kepemimpinan dikaitkan dengan jenis kelamin perempuan, tentu menjadikan kepemimpinan perempuan memiliki fenomena tersendiri untuk dijadikan kajian secara serius dan mendalam, terutama pada jenjang RA.Berdasarkan data perkembanganselama 6 tahun terakhr, kepala RA perempuan di Kabupaten Pati bahwa pada tahun 2011 berjumlah 188 orang, jumlah ini terus bertambah di tahun 2012 menjadi 193 orang. Pada tahun 2013 mencapai 200 orang, sedangkan tahun 2014 mencapai 2010 orang bahwan tahun 2015 mencapai 2017 orang. Jumlah itu terus bertambahdi tahun 2016 bertambah menjadi 221(Data IGRA, 2016). Data tersebut sebagai gambaran kepercayaan masyarakat Pati akan kemampuan perempuan dalam memimpin lembaga pendidikan.Di jenjang pendidikan ini secara kuantitatif menunjukkan siklus terbalik dengan jenjang pendidikan ke atas setelahnya.

Kondisi tersebut menunjukkan bahwa adanya faktor yang menjadi pendorong mengapa kepemimpinan kepala sekolah pada jenjang RA tersebut menjadi mayoritas. Faktor utama karena performansi kepala RA perempuan di Kabupaten Pati. Performansi diartikan sebagai tingkat atau derajat pelaksanaan tugas seseorang atas dasar kompetensi dan standar kerja yang telah ditetapkan (Salam, 2014).Performansi adalah prestasi kerja atau unjuk kerja (Muyasa, 2005). Selama ini performansi kepala RA perempuan didasarkan pada pengetahuan, sikap, ketrampilan dan motivasi didalam menjalankan tugas kerjanya sesuai dengan tanggung jawab yang diberikan kepadanya sebagai kepala RA perempuan sehingga bisa mendapatkan kepercayaan masyarakat.

Performansi kepala RA perempuan menjadi maksimal besar kemungkinan dipengaruhi oleh kecerdasan emosional. Menurut Daniel Goleman kecerdasan emosi menentukan potensi kita untuk mempelajari keterampilan-keterampilan praktis yang didasarkan pada lima unsurnya: kesadaran diri, motivasi, pengaturan diri, empati, dan kecakapan dalam 
membina hubungan dengan orang lain (Goleman, 2005). Oleh karena itu ketika orang memiliki kecerdasan emosi, maka mereka akan memiliki kemampuan memotivasi diri sendiri dan bertahan menghadapi frustasi, mengandalkan dorongan hati dan tidak berlebih-lebihan dalam kesenangan, mengatur suasana hati dan menjaga agar bebas dari stres, tidak melumpuhkan kemampuan berpikir, berempati, dan berdoa.

Faktor yang bisa meningkatkan performansi kepala RA perempuan adalah gaya kepemimpinan demokratis yang dimilikinya. Kepemimpinan demokratis adalah kepemimpinan yang aktif, dinamis, dan terarah. Pembagian tugas disertai dengan pelimpahan wewenang dan tanggung jawab yang jelas memungkinkan agar setiap anggotanya berpartisipasi secara aktif (Daryanto, 2011). Hal tersebut bertujuan agar setiap anggota mengetahui secara pasti sumbangan yang dapat diberikan untuk mencapai tujuan organisasi.

Gaya kepemimpinan demokratis yang gunakan oleh kepala RA perempuan di Kabupaten Pati terlihat dari usaha mereka untuk memanfaatkan setiap orang yang dipimpinya. Anggota diberikan kesempatan untuk berpartisipasi dalam setiap kegiatan. Partisipasi tersebut disesuaikan dengan jabatan dan jenis kemampuan setiap anggota. Selain itu kepala RA perempuan di Kabupaten Pati dalam setiap pengambilan keputusan lebih mementingkan musyawarah, sehingga dalam pelaksanaan setiap keputusan bisa meminimalisir anggota yang merasa terpaksa.Dari sisi kuantitas keberabadaan yang mayoritas seolah memberikan kesan bahwa lembaga pendidikan RA seolah lekat dengan kepemimpinan perempuan yang demokratis.

Gambaran mayoritas kepemimpinan kepala RA yang ada di Kabupaten Pati bisa ditinjau dari berbagai aspek. Tidak hanya sekedar tinjuan kuantitas saja, namun bisa mengarah kepada performansi yang mereka tampilkan. Dalam pandangan Abdus Salam performansi (kinerja) merupakan kualitas dan kuantitas dari suatu hasil kerja (output) individu maupun kelompok dalam suatu aktivitas tertentu yang diakibatkan oleh kemampuan alami atau kemampuan yang diperoleh dari peroses berlajar serta keinginan untuk berprestasi (Salam, 2005). Oleh sebab itu performansi (kinerja) yang mereka capai telah 
menumbuhkan kepercayaan masyarakat dan pengelola pendidikan, karena mereka bisa membawa individu maupun kelompoknya memiliki kinerja yang tinggi. Performansi yang baik tersebut dapat tergambar dari adanya budaya kerja yang berorientasi pada prestasi, memiliki percaya diri, pengendalian diri, dan memiliki kompetensi yang baik.

Berdasarkan latar belakang di atas, menjadi ketertarikan tersendiri bagi peneliti untuk melakukan penelitian terkait dengan kepemimpinan perempuan di lembaga pendidikan RA di Kabupaten Pati dengan tujuan penelitian yaitu untuk mengetahuipengaruh kecerdasan emosional dan gaya kepemimpinan demokratis terhadap performansi kepala RAperempuan di Kabupaten Pati.Penelitian ini merupakan penelitian kuantitatif. Disebut metode kuantitatif karena data penelitian berupa angka-angka dan analisis menggunakan statistik (Sugiyono, 2010).Populasi penelitian adalah kepala RA di Kabupaten Pati sebanyak 221 orang dengan sampel 135 orang. Pengolahan data menggunakan software SPSS 17. Statistik yang digunakan untukmenganalisa data adalah analisa regresi ganda. Statistik ini digunakan untuk mengetahui pengaruh variabel kecerdasan emosional $\left(\mathrm{X}_{1}\right)$ dan kepemimpinan demokratis $\left(\mathrm{X}_{2}\right)$, secara simultan terhadapa variabel performansi Kepala RA (Y).

\section{B. HASIL PENELITIAN DAN PEMBAHASAN}

\section{Hasil Penelitian}

Berdasarkan hasil perhitungan SPSS pada data variabel kecerdasan emosional diperoleh data di dalam tabel berikut:

Tabel B.1. Statistik Deskriptif Variabel $\mathrm{X}_{1}$

\begin{tabular}{|c|c|c|c|c|c|c|}
\hline Variabel & N & Mean & Median & Min & Max & Range \\
\hline Kecerdasan Emosional $\left(\mathrm{X}_{1}\right)$ & 135 & 152,50 & 151 & 115 & 185 & 70 \\
\hline
\end{tabular}

Sumber : Hasil Pengolahan, 2016

Hasil di atas menunjukkan bahwa mean kecerdasan emosional $\left(\mathrm{X}_{1}\right)$ adalah 152,50 dari tergolong cukupkarena termasuk dalam interval (157-144), artinya Kepala 
RA Perempuan di Kabupeten Pati memiliki kecerdasan emosional yang cukup baik.

Berdasarkan hasil perhitungan SPSS pada data variabel kepemimpinan demokratis $\left(\mathrm{X}_{2}\right)$ diperoleh data di dalam tabel berikut:

Tabel B.2.. Statistik Deskriptif Variabel $\mathrm{X}_{2}$

\begin{tabular}{|c|c|c|c|c|c|c|}
\hline Variabel & N & Mean & Median & Min & Max & Range \\
\hline Kepemimpinan Demokratis $\left(\mathrm{X}_{2}\right)$ & 135 & 83,66 & 84 & 60 & 100 & 40 \\
\hline
\end{tabular}

Sumber : Hasil Pengolahan, 2016

Hasil di atas menunjukkan mean kepemimpinan demokratis $\left(\mathrm{X}_{2}\right)$ adalah 83,66 tergolong cukupkarena termasuk dalam interval (84 - 77), artinya kepala RA Perempuan di Kabupaten Pati memiliki Kepemimpinan yang cukup demokratis.

Berdasarkan hasil perhitungan SPSS pada data variabel performansi Kepala RA (Y) diperoleh data di dalam tabel berikut:

Tabel B.3. Statistik Deskriptif Variabel Y

\begin{tabular}{|c|c|c|c|c|c|c|}
\hline Variabel & N & Mean & Median & Min & Max & Range \\
\hline Performansi Kepala RA (Y) & 135 & 168 & 168 & 135 & 200 & 65 \\
\hline
\end{tabular}

Sumber : Hasil Pengolahan, 2016

Hasil di atas menunjukkan mean performansi Kepala RA (Y) adalah 168tergolong cukupkarena termasuk dalam interval (174-162), artinya Kepala RA memiliki performansi yang cukup baik.

1. PengaruhKecerdasan Emosional $\left(X_{I}\right)$ terhadap Performansi KepalaRA $(Y)$

Berdasarkan hasil perhitungan SPSS diperoleh data di dalam tabel berikut:

Tabel B.4. Hail Uji Persamaan Regresi $X_{1}$ terhadap Y

Coefficients $^{\mathrm{a}}$

\begin{tabular}{|l|c|c|c|c|}
\hline Model & $\begin{array}{c}\text { Unstandardized } \\
\text { Coefficients }\end{array}$ & $\begin{array}{c}\text { Standardized } \\
\text { Coefficients }\end{array}$ & $\mathrm{t}$ & Sig. \\
\hline
\end{tabular}




\begin{tabular}{|c|c|c|c|c|c|c|}
\hline & & B & Std. Error & Beta & & \\
\hline \multirow[t]{2}{*}{1} & (Constant) & 138.882 & 13.240 & & 10.489 & .000 \\
\hline & Kecerdasan Emosional (X1) & .191 & .086 & .188 & 2.208 & .029 \\
\hline
\end{tabular}

a. Dependent Variable: Performansi Kepala RA (Y)

Sumber : Hasil Pengolahan, 2016

Tabeltersebut memberikan informasi tentang persamaan regresi bahwa $\mathrm{Y}=$ $138,882+0,191 X$. Diperoleh informasi pula bahwa baik skor konstan maupun beta masing-masing signifikan, yakni diperoleh skor probabilitas (Sig.) 0,000 dan 0,029 yang berarti lebih kecil dibandingkan dengan taraf signifikansi 0,05. Selanjutnya hasil analisis ANOVA yang digunakan untuk menganalisis data pengaruh variabel kecerdasan emosional $\left(\mathrm{X}_{1}\right)$ terhadap performansi Kepala RA (Y)disajikan dalam tabel berikut:

Tabel B.5.

Pengaruh Kecerdasan Emosional $\left(\mathrm{X}_{1}\right)$ terhadap Performansi Kepala RA (Y)

\begin{tabular}{|l|r|r|r|r|r|}
\hline \multicolumn{7}{|c|}{ ANOVA $^{\mathrm{b}}$} \\
\hline Model & Sum of Squares & df & Mean Square & F & Sig. \\
\hline $1 \quad$ Regression & 943.652 & 1 & 943.652 & 4,877 & $.029^{\mathrm{a}}$ \\
Residual & 25736.348 & 133 & 193.506 & & \\
Total & 26680.000 & 134 & & & \\
\hline
\end{tabular}

a. Predictors: (Constant), Kecerdasan Emosional (X1)

b. Dependent Variable: Performansi Kepala RA (Y)

Sumber : Hasil Pengolahan, 2016

Hasil perhitungan ANOVA diperoleh informasi perhitungan $\mathrm{F}$ sebesar 4,877 dan probabilitas (Sig.) 0,029 yang berarti lebih kecil dibandingkan dengan taraf signifikansi 0,05, sehingga diambil keputusan bahwa Ho ditolak. Ini karena Sig. $0,029<0,05$. Sehingga disimpulkan bahwa kecerdasan emosional $\left(\mathrm{X}_{1}\right)$ berpengaruh terhadap performansi Kepala RA (Y). Selanjutnya hasil analisis korelasi untuk mengetahui kontribusi pengaruh variabel kecerdasan emosional $\left(\mathrm{X}_{1}\right)$ terhadap performansi Kepala RA (Y) disajikan dalam tabel berikut: 
Tabel B.6.

Hasil Analisis Kontribusi Variabel Kecerdasan Emosional $\left(X_{1}\right)$ terhadap Performansi Kepala RA (Y)

\begin{tabular}{|r|r|r|r|r|}
\hline \multicolumn{5}{|c|}{ Model Summary $^{\mathrm{b}}$} \\
Model & $\mathrm{R}$ & $\mathrm{R}$ Square & $\begin{array}{c}\text { Adjusted } \mathrm{R} \\
\text { Square }\end{array}$ & $\begin{array}{c}\text { Std. Error of the } \\
\text { Estimate }\end{array}$ \\
\hline 1 & $.188^{\mathrm{a}}$ & .035 & .028 & 13.911 \\
\hline
\end{tabular}

a. Predictors: (Constant), Kecerdasan Emosional (X1)

b. Dependent Variable: Performansi Kepala RA (Y)

Sumber : Hasil Pengolahan, 2016

Bila menggunakan $r$ tabel untuk $\mathrm{n}=150$ dan kesalahan $5 \%$ maka $r$ tabel $=$ 0,159 sedangkan untuk $r$ hitung adalah 0,188 . Dari hasil perhitungan ternyata $r$ hitung lebih besar dari $r$ tabel maka Ho diterima dan Ha ditolak. Hasil perhitungan korelasi yang tersaji dalam tabel menunjukkan ditunjukkan hasi $\mathrm{R}^{2}$ sebesar 0,035. Ini berarti besaran pengaruh variabel kecerdasan emosional $\left(\mathrm{X}_{1}\right)$ terhadap performansi Kepala RA (Y) adalah sebesar 3,5\%, sedangkan sisanya sebesar $96,5 \%$ dipengaruhi oleh variabel lain yang tidak tercakup dalam penelitian ini.

\section{PengaruhKepemimpinan Demokratis $\left(X_{2}\right)$ terhadap Performansi Kepala RA}

(Y)

Berdasarkan hasil perhitungan SPSS diperoleh data di dalam tabel berikut:

Tabel B.7. Hasil Uji Persamaan Regresi $X_{2}$ terhadap $Y$

\begin{tabular}{|c|c|c|c|c|c|c|}
\hline \multicolumn{7}{|c|}{ Coefficients $^{a}$} \\
\hline & \multirow[t]{2}{*}{ Model } & \multicolumn{2}{|c|}{ Unstandardized Coefficients } & $\begin{array}{c}\text { Standardized } \\
\text { Coefficients }\end{array}$ & \multirow[t]{2}{*}{$\mathrm{t}$} & \multirow[t]{2}{*}{ Sig. } \\
\hline & & B & Std. Error & Beta & & \\
\hline \multirow[t]{2}{*}{1} & (Constant) & 137.984 & 12.420 & & 11.110 & .000 \\
\hline & Kepemimpinan Demokrasi (X2) & .359 & .148 & .206 & 2.428 & .017 \\
\hline
\end{tabular}

a. Dependent Variable: Performansi Kepala RA (Y)

Sumber : Hasil Pengolahan, 2016 
QUALITY

Volume 5, Nomor 1, 2017: 170-189

Tabeltersebut memberikan informasi tentang persamaan regresi yaitu bahwa $\mathrm{Y}=137,984+0,359 \mathrm{X}$. Diperoleh informasi pula bahwa baik skor konstan maupun beta masing-masing signifikan, yakni diperoleh skor probabilitas (Sig.) 0,00 dan 0,017 yang berarti lebih kecil dibandingkan dengan taraf signifikansi 0,05. Selanjutnya hasil analisis ANOVA yang digunakan untuk menganalisis data pengaruh variabel Kepemimpinan Demokratis $\left(\mathrm{X}_{2}\right)$ terhadap Performansi Kepala RA (Y) disajikan dalam tabel berikut:

Tabel B.8.

Pengaruh Kepemimpinan Demokratis $\left(\mathbf{X}_{2}\right)$ terhadap Performansi Kepala RA (Y)

\begin{tabular}{|l|r|r|r|r|r|}
\hline \multicolumn{7}{|c|}{ ANOVA $^{\mathrm{b}}$} \\
\hline 1 Redel & Sum of Squares & df & Mean Square & F & Sig. \\
\hline Residual & 1132.329 & 1 & 1132.329 & 5.895 & $.017^{\mathrm{a}}$ \\
Total & 25547.671 & 133 & 192.088 & & \\
\hline
\end{tabular}

a. Predictors: (Constant), Kepemimpinan Demokrasi (X2)

b. Dependent Variable: Performansi Kepala RA (Y)

Sumber : Hasil Pengolahan, 2016

Hasil perhitungan ANOVA tersebut diperoleh informasi tentang hasil perhitungan F sebesar 5,895 dan probabilitas (Sig.) 0,017 yang berarti lebih kecil dibandingkan dengan taraf signifikansi 0,05, sehingga dapat diambil keputusan bahwa Ho ditolak. Ini karena Sig. 0,017<0,05. Oleh karena itu dapat disimpulkan bahwa Kepemimpinan Demokratis $\left(\mathrm{X}_{2}\right)$ berpengaruh terhadap Performansi Kepala RA (Y). Selanjutnya hasil analisis korelasi untuk mengetahui kontribusi pengaruh variabel Kepemimpinan Demokratis $\left(\mathrm{X}_{2}\right)$ terhadap Performansi Kepala RA (Y) disajikan dalam tabel berikut:

Tabel B.9. Hasil Analisis Kontribusi Variabel Kepemimpinan Demokratis $\left(\mathrm{X}_{2}\right)$ terhadap Performansi Kepala RA (Y)

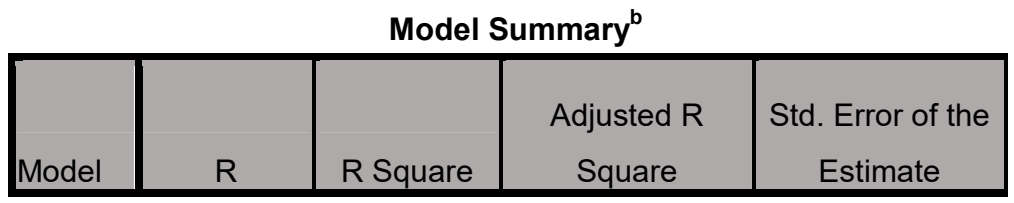




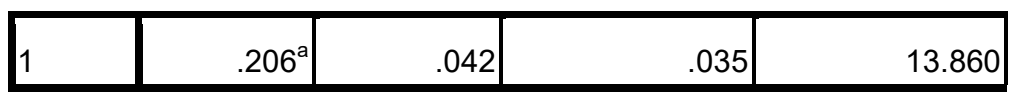

a. Predictors: (Constant), Kepemimpinan Demokrasi (X2)

b. Dependent Variable: Performansi Kepala RA (Y)

Sumber : Hasil Pengolahan, 2016

Bila menggunakan $r$ tabel untuk $\mathrm{n}=150$ dan kesalahan $5 \%$ maka $r$ tabel $=$ 0,159 sedangkan untuk $r$ hitung adalah 0,206. Dari hasil perhitungan ternyata $r$ hitung lebih besar dari $r$ tabel maka Ho diterima dan Ha ditolak. Hasil perhitungan korelasi yang tersaji dalam tabel tersebut ditunjukkan hasi $\mathrm{R}^{2}$ sebesar 0,042 . Ini berarti besaran pengaruh variabel kepemimpinan demokratis $\left(\mathrm{X}_{2}\right)$ terhadap performansi Kepala RA (Y) adalah sebesar 4,2\%, sedangkan sisanya sebesar 95,8\% dipengaruhi oleh variabel lain yang tidak tercakup dalam penelitian ini.

\section{PengaruhKecerdasan Emosional $\left(X_{1}\right)$ dan Kepemimpinan Demokratis $\left(X_{2}\right)$ terhadap Performansi Kepala RA (Y)}

Analisa regresi ganda digunakanuntuk mengetahui pengaruh variabel kecerdasan emosional $\left(\mathrm{X}_{1}\right)$ dan kepemimpinan demokratis $\left(\mathrm{X}_{2}\right)$, secara simultan terhadapvariabel performansi Kepala RA (Y).Uji regresi ganda digunakan untuk mengetahui pengaruh masing-masing variabel independen terhadap variabel dependen. Berdasarkan hasil perhitungan SPSS diperoleh data di dalam tabel berikut:

Tabel B.10. Hasil Pengujian Regresi Ganda

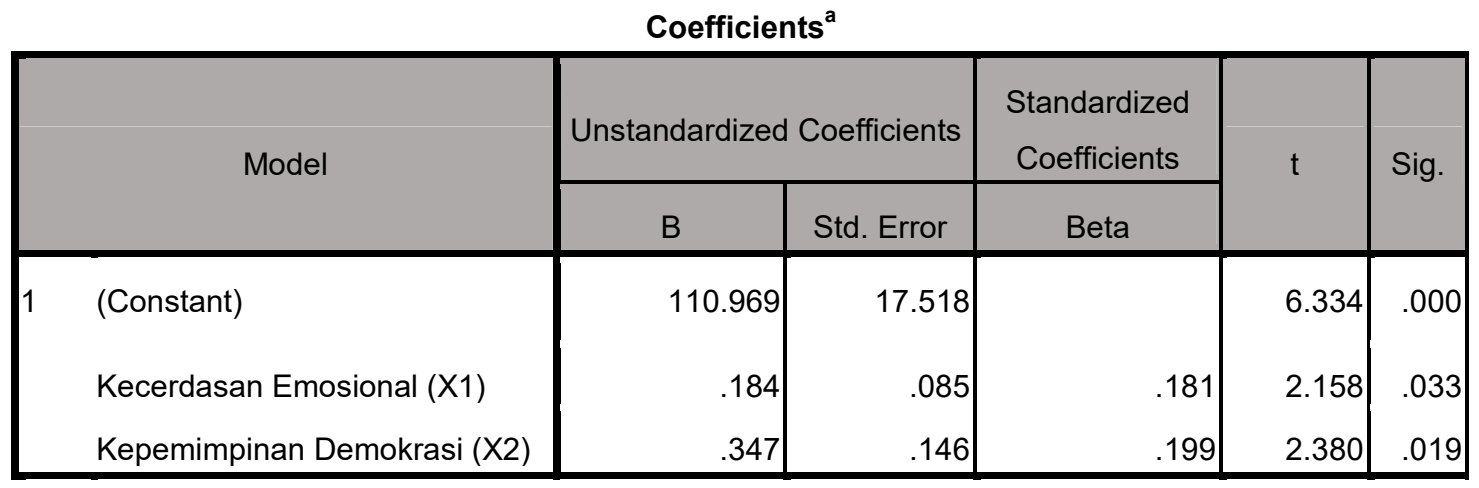

a. Dependent Variable: Performansi Kepala RA (Y) 
QUALITY

Volume 5, Nomor 1, 2017: 170-189

Sumber : Hasil Pengolahan, 2016

Dari kedua variabel independen yang dimasukkan dalam model variabel Kecerdasan Emosional $\left(\mathrm{X}_{1}\right)$ dan Kepemimpinan Demokratis $\left(\mathrm{X}_{2}\right)$ signifikan pada 0,05. Dari sini dapat disimpulkan bahwa Performansi Kepala RA (Y) dipengaruhi oleh Kecerdasan Emosional $\left(\mathrm{X}_{1}\right)$ dan Kepemimpinan Demokratis $\left(\mathrm{X}_{2}\right)$ dengan persamaan matematis: $\mathrm{Y}=110,969+0,184\left(\mathrm{X}_{1}\right)+0,347\left(\mathrm{X}_{2}\right)$. Berdasarkan persamaan diatas, dapat dijelaskan bahwa:

1) Konstanta sebesar 110,969 menyatakan bahwa jika variabel independen dianggap konstan, maka Performansi Kepala RA (Y) sebesar 110,969.

2) Koefisien regresi Kecerdasan Emosional $\left(X_{1}\right)$ sebesar 0,184 menyatakan bahwa setiap kenaikan kecerdasan emosional 1\% akan meningkatkan Performansi Kepala RA 0,184\%.

3) Koefisien regresi Kepemimpinan Demokratis $\left(\mathrm{X}_{2}\right)$ sebesar 0,347 menyatakan bahwa setiap kenaikan Kepemimpinan Demokratis 1\% akan meningkatkan Performansi Kepala RA 0,347\%.

Tabel 17. Pengaruh Variabel $X_{1}$, dan $X_{2}$ terhadap $Y$

ANOVA $^{b}$

\begin{tabular}{|l|r|r|r|r|r|}
\hline \multicolumn{1}{|c|}{ Model } & Sum of Squares & df & Mean Square & F & Sig. \\
\hline Regression & 2002.668 & 2 & 1001.334 & 5.356 & $.006^{\mathrm{a}}$ \\
Residual & 24677.332 & 132 & 186.949 & & \\
Total & 26680.000 & 134 & & & \\
\hline
\end{tabular}

a. Predictors: (Constant), Kepemimpinan Demokrasi (X2), Kecerdasan Emosional (X1)

b. Dependent Variable: Performansi Kepala RA (Y)

Sumber : Hasil Pengolahan, 2016

Hasil perhitungan ANOVA diperoleh informasi tentang hasil perhitungan $\mathrm{F}$ sebesar 5,356 dan probabilitas (Sig.) 0,006 yang berarti lebih kecil dibandingkan dengan taraf signifikansi 0,05, sehingga diambil keputusan bahwa Ho ditolak. Oleh karena itu dapat disimpulkan bahwa variabel Kecerdasan Emosional $\left(\mathrm{X}_{1}\right)$ dan kepemimpinan demokratis $\left(\mathrm{X}_{2}\right)$ berpengaruh terhadap performansi Kepala RA (Y). Selanjutnya hasil analisis korelasi untuk mengetahui kontribusi pengaruh 
variabel Kecerdasan emosional $\left(\mathrm{X}_{1}\right)$ dan kepemimpinan demokratis $\left(\mathrm{X}_{2}\right)$ terhadap performansi Kepala RA (Y)disajikan dalam tabel berikut:

Tabel B.11. Hasil Analisis Kontribusi Variabel X1, X2,X3 dengan Y

\begin{tabular}{|l|r|r|r|r|}
\multicolumn{7}{|c|}{ Model Summary $^{\mathbf{b}}$} \\
\hline Model & $\mathrm{R}$ & $\mathrm{R}$ Square & $\begin{array}{c}\text { Adjusted R } \\
\text { Square }\end{array}$ & $\begin{array}{c}\text { Std. Error of the } \\
\text { Estimate }\end{array}$ \\
\hline 1 & $.274^{\mathrm{a}}$ & .075 & .061 & 13.673 \\
\hline
\end{tabular}

a. Predictors: (Constant), Kepemimpinan Demokrasi (X2), Kecerdasan Emosional (X1)

b. Dependent Variable: Performansi Kepala RA (Y)

Sumber : Hasil Pengolahan, 2016

Bila menggunakan $r$ tabel untuk $\mathrm{n}=150$ dan kesalahan $5 \%$ maka $r$ tabel $=0,159$ sedangkan untuk $r$ hitung adalah 0,274. Dari hasil perhitungan ternyata $r$ hitung lebih besar dari $r$ tabel maka Ho diterima dan Ha ditolak. Hasil perhitungan korelasi yang tersaji dalam tabel tersebut ditunjukkan hasi $\mathrm{R}^{2}$ sebesar 0,075 . Ini berarti besaran pengaruh variabel Kecerdasan Emosional $\left(\mathrm{X}_{1}\right)$ dan Kepemimpinan Demokratis $\left(\mathrm{X}_{2}\right)$ terhadap Performansi Kepala RA (Y) adalah sebesar 7,5\%, sedangkan sisanya sebesar 92,5\% dipengaruhi oleh variabel lain yang tidak tercakup di dalam penelitian ini.

\section{PEMBAHASAN}

\section{Performansi Kepala Sekolah}

Performansi merupakan hasil dari suatu pekerjaan yang berkaitan dengan hasil kerja, prestasi kerja, pencapaian target yang telah ditentukan, secara kuantitatif maun kualitatif baik yang dilakukan secara individu sebagai pekerjaan maupun oleh organisasi (Suhardiman, 2012). Pada sisi ini performansi merupakan hasil kerja yang telah dicapai oleh seseorang atau kelompok orang dalam suatu organisasi sesuai dengan wewenang dan 
QUALITY

Volume 5, Nomor 1, 2017: 170-189

tanggung jawabnya masing-masing dalam rangkan untuk mencapai tujuan organisasi bersangkutan secara legal, tidak melanggar hukum dan sesuai dengan norma maupun etika.

SedangkanKepala sekolah/madrasah adalah guru yang diberi tugas tambahan untuk memimpin taman kanak-kanak/raudhotul athfal (TK/RA), taman kanak-kanak luar biasa (TKLB), sekolah dasar/madrasah ibtidaiyah (SD/MI), sekolah dasar luar biasa (SDLB), sekolah menengah pertama/madrasah tsanawiyah (SMP/MTs), sekolah menengah pertama luar biasa (SMPLB), sekolah menengah atas/madrasah aliyah (SMA/MA), sekolah menengah kejuruan/madrasah aliyah kejuruan (SMK/MAK), atau sekolah menengah atas luar biasa (SMALB) yang bukan sekolah bertaraf internasional (SBI) atau yang tidak dikembangkan menjadi sekolah bertaraf internasional (SBI) (Peraturan Menteri Pendidikan Nasional nomor 28 tahun 2010). Berdasarkan pada pengertian yang telah disebutkan dapat dijelaskan bahwa kepala sekolah adalah seorang guru yang memiliki kedudukan yang diangkat berdasarkan prosedur dan persyaratan tertentu, untuk memimpin sekolah sesuai dengan tugas dan tanggung jawab yang diembankan kepadanya.

Dengan dirumuskanya pengertian performansi dan kepala sekolah, maka menjadi jelas bahwa performansi yang dimaksdukan dalam penelitian ini adalah performansi kepala sekolah. Sehingga arah yang hendak diukur adalah performansi yang telah dicapai oleh seorang kepala sekolah selama masa periode tertentu. Dalam konteks tersebut maka performansi adalah hasil kerja dalam mencapai suatu tujuan atau persyaratan pekerjaan yang telah ditetapkan. Maka adanya performansi senantiasa dibandingkan antara hasil yang telah dicapai dengan target yang ditentukan sebelumnya oleh seorang kepala sekolah.

Untuk menilai keberhasilan performansi seorang kepala sekolah maka sangat perlu untuk meninjau kembali peran-fungsi dari kepala sekolah tersebut. Karena pada hakekatnya peran-fungsi kepala sekolah merupakan untuk mengimplementasikan visi misi dari lembaga pendidikan yang 
QUALITY

Volume 5, Nomor 1, 2017: 170-189

dipimpinnya. Oleh karena itu keberhasilan antara kepala sekolah di tempat yang satu, akan berbeda dengan keberhasilan kepala sekolah di tempat yang lain. Sehingga pada sisi ini untuk mengukur sejauh mana keberhasilan atau performansi yang ditampilkan oleh seorang kepala sekolah sangat tergantung dari sejuah mana visi dan misi lembaga yang dipimpinnya dapat tercapai. Menurut E. Mulyasa kepala sedikitnya harus mampu berperan sebagai edukator, manajer, administrator, supervisor, leader, innovator, dan motivator (Mulyasa, 2006).

\section{KecerdasanEmosional}

Kcerdasan emosional merupakan kemampuan mengenali perasaan kita sendiri dan perasaan orang lain, kemampuan memotivasi diri sendiri dan kemampuan mengelola emosi dengan baik pada diri sendiri dan dalam hubungan dengan orang lain (Goleman, 2005). Sehingga secara sederhana kecerdasan emosional diartikan sebagai penggunaan emosi secara cerdas (Masaong \& Arfan A. Tilomi, 2011). Dengan demikian maka kecerdasan emosional untuk memahami sesuatu yang ada di sekeliling kita degan baik. Menurut Salovy dan Mayer sebagaimana yang dikutip Daniel Goleman menyatakan bahwa wilayah kecerdasan emosional mencakup wilayah: mengenali emosi diri, mengelola emosi, memotivasi diri sendiri, mengenali emosi orang lain dan membina hubungan sosial (Goleman, 2005).

1) Mengenali emosi diri.

Mengenali emosi diri merupakan kecakapan pribadi untuk mengetahui kondisi diri sendiri, kesukaan, sumber daya dan intuisi yang meliputi : (1) Kesadaran emosi: mengenali emosi diri sendiri dan efeknya. (2) Penilaian diri secara teliti: mengetahui kekuatan dan batas-batas diri sendiri. (3) Percaya diri: keyakinan tentang harga diri dan kemampuan sendiri.

2) Mengelola emosi.

Mengelola emosi tercermin dalam kecakapan pribadi pengaturan diri untuk mengelola kondisi, implus dan sumber daya diri sendiri yang 
meliputi: (1) Kendali diri: mengelola emosi dan desakan-desakan hati yang merusak. (2) Sifat dapat dipercaya: memelihara norma kejujuran dan integritas. (3) Kewaspadaan: bertanggung jawab atas kinerja pribadi. (4) Adaptabilitas: keluwesan dalam menghadapi perubahan. (5) Inovasi: mudah menerima dan terbuka terhadap gagasan, pendekatan, dan informasi-informasi baru.

3) Memotivasi diri sendiri.

Memotivasi diri sendiri merupakan kecenderungan emosi yang mengantar atau memudahkan peraihan sasaran. Hal ini dapat tercermin dalam: (1) Dorongan prestasi: dorongan untuk menjadi lebih baik atau memenuhi standar keberhasilan. (2) Komitmen: menyesuaikan diri dengan sasaran kelompok. (3) Inisiatif: kesiapan untuk memanfaatkan kesempatan. (4) Optimisme: kegigihan dalam memperjuangkan sasaran kendati ada halangan dan kegagalan.

4) Mengenali emosi orang lain (Empati).

Mengenali emosi orang lain merupakan kesadaran terhadap perasaan, kebutuhan dan kepentingan orang lain. Dengan demikian mengenali emosi orang lain merupakan kecakapan sosial empati, yang dalam hal ini meliputi: (1) Memahami orang lain: mengindra perasaan dari perspektif orang lain, dan menunjukkan minat aktif terhadap kepentingan orang lain. (2) Orientasi pelayanan: mengantisipasi, mengenali dan berusaha memenuhi kebutuhan pelanggan. (3) Mengembangkan orang lain: merasakan kebutuhan perkembangan orang lain dan berusaha menumbuhkan kemampuan mereka. (4) Mengatasi keragaman: menumbuhkan peluang melalui pergaulan dengan bermacam-macam orang. (5) Kesadaran politis: mampu membaca arus-arus emosi sebuah kelompok dan hubungannya dengan kekuasaan.

5) Membina hubungan sosial.

Membina hubungan merupakan kesadaran terhadap perasaan, kebutuhan, dan kepentingan orang lain. Sehingga kecapakan sosial ini berupa keterampilan sosial yang meliputi: (1) Pengaruh: memiliki taktik- 
taktik untuk melakukan persuasi. (2) Komunikasi: mengirim pesan yang jelas dan meyakinkan. (3) Kepemimpinan: membangkitkan inspirasi dan memandu kelompok dan orang lain. (4) Katalisator: memulai dan mengelola perubahan. (5) Manajemen konflik: negosiasi dan pemecahan silang pendapat. (6) Pengikat jaringan: menumbuhkan hubungan sebagai alat. (7) Kolaborasi dan kooperasi : kerja sama dengan orang lain demi tujuan bersama. (8) Kemampuan tim: menciptakan sinergi kelompok dalam memperjuangkan tujuan bersama.

Dari kelima wilayah tersebut, kemampuan setiap individu dengan individu yang lain sangat bereda-beda dalam wilayah-wilayah ini. Kadang kita melihat orang teramat pandai dan terampil dalam menangani kecemasan dirinya sendiri, tetapi agak kerepotan dalam meredam kemarahan orang lain. Hal yang mendasari dari perbedaan yang dimiliki oleh setiap individu adalah saraf yang bekerja pada limbik sistem yang dimilikinya.

\section{KepemimpinanDemokratis}

Menurut Sudarwan Danim ada beberapa ciri dari kepemimpinan demokratis adalah (a) Beban kerja organisasi menjadi tanggung jawab bersama, (b) Pimpinan menganggap bawahan sebagai komponen pelaksana, dan secara integral harus diberi tugas dan tanggung jawab, (c) Disiplin, tetapi tidak kaku, jika ada masalah diselesaikan bersama, (d) Memiliki kepercayaan yang tinggi terhadap bawahan dengan tidak melepaskan tanggung jawab pengawasan. (e) Komunikasi bersifat terbuka dan dua arah (Sudarwan Danim, 2014).Sondang P. Siagian dalam Ngalim Purwanto menyatakan bahwa pemimpin yang demokratis memiliki sifat-sifat sebaagaimana berikut: (a) Dalam menggerakkan bawahan bertitik tolak dari anggapan bahwa manusia merupakan makhluk yang paling mulia di dunia. (b) Senang menerima saran, pendapat dan kritik dari bawahan. (c) Mengutamakan kerja sama dalammencapai tujuan. (d) Memberikan kebebasan kepada bawahan tetapi juga tetap membimbingnya (Sondang, 2011). 
Dari sifat-sifat yang harus dimiliki oleh pemimpin tipe demokratis, jelaslah bahwa tidak mudah untuk menjadi pemimpin demokratis. Pemimpin demokratis berbaur di tengah anggota kelompoknya. Hubungan pemimpin dengan anggota bukan sebagai majikan dengan bawahan, bentuk human relationship atas dasar prinsip saling harga-menghargai dan hormatmenghormati. Dalam tindakan dan usaha-usahanya selalu berpangkal kepada kepentingan dan kebutuhan kelompoknya, dan mempertimbangkan kesanggupan dan kemampuan kelompoknya.

\section{a) Pengaruh Kecerdasan Emosional $\left(X_{I}\right)$ terhadap Performansi KepalaRA (Y)}

Hasil perhitungan ANOVA tersebut diperoleh informasi tentang hasil perhitungan F sebesar 4,877 dan probabilitas (Sig.) 0,029 yang berarti lebih kecil dibandingkan dengan taraf signifikansi 0,05, sehingga dapat diambil keputusan bahwa Ho ditolak. Ini karena Sig. 0,029<0,05. Oleh karena itu dapat disimpulkan bahwa kecerdasan emosional (X1) berpengaruh terhadap Performansi Kepala RA (Y). Bila menggunakan $\mathrm{r}$ tabel untuk $\mathrm{n}=150$ dan kesalahan $5 \%$ maka $\mathrm{r}$ tabel $=$ 0,159 sedangkan untuk $r$ hitung adalah 0,188 . Dari hasil perhitungan ternyata $r$ hitung lebih besar dari $r$ tabel maka Ho diterima dan Ha ditolak.

Kepala RA Perempuan di Kabupeten Pati memiliki kecerdasan emosional yang cukup baik. Kecerdasan emosional terebut merupakan kemampuan mengenali emosi diri sendiri, kemampuan mengendalikan emosi dan mengambil tindakan yang tepat, kemampuan mengenali emosi orang lain dan kemampuan bertindak dan berinteraksi dengan orang lain.Kepala RA dituntut dapat mengelola lembaga yang dipimpinnya dengan baik, sehingga dapat mewujudkan visi dan misinya. Dengan memiliki kemampuan mengelola emosi yang baik tentunya akan mampu melaksanakan tugas pokok, fungsi dan tanggung jawab yang diberikan kepadanya dengan baik pula.

Berdasarkan uraian dan hasil penelitian ini dapat dijelaskan, bahwa semakin tinggi kecerdasan emosional, maka semakin tinggi pula performansi yang ditorehkan oleh Kepala RA. Sebaliknya, semakin kurang kecerdasan 
QUALITY

Volume 5, Nomor 1, 2017: 170-189

emosionalnya, maka Kepala RA semakin sulit untuk memperoleh performansi terbaiknya.

\section{b) Pengaruh Kepemimpinan Demokratis (X2) terhadap Performansi Kepala}

\section{RA (Y)}

Hasil perhitungan ANOVA tersebut diperoleh informasi tentang hasil perhitungan F sebesar 5,895 dan probabilitas (Sig.) 0,017 yang berarti lebih kecil dibandingkan dengan taraf signifikansi 0,05, sehingga dapat diambil keputusan bahwa Ho ditolak. Ini karena Sig. 0,017<0,05. Oleh karena itu dapat disimpulkan bahwa kepemimpinan demokratis (X2) berpengaruh terhadap performansi Kepala RA (Y). Bila menggunakan $r$ tabel untuk $n=150$ dan kesalahan $5 \%$ maka $r$ tabel $=0,159$ sedangkan untuk $\mathrm{r}$ hitung adalah 0,206. Dari hasil perhitungan ternyata $\mathrm{r}$ hitung lebih besar dari $r$ tabel maka Ho diterima dan Ha ditolak.

Pemimpian demokratis senantiasa memberikan kesempatan yang seluasluasnya kepada bawahannya untuk mengeksplorasi kemampuannya sambil mengawasinya sesuai dengan aturan dan peraturan yang berlaku. Dengan gaya kepemimpinan demokratis, Kepala RA di kabupaten Pati mampu menunjukkan tingkat performansi yang cukup berhasil. Berdasarkan uraian dan hasil penelitian ini dapat dijelaskan, bahwa semakin demokrastis Kepala RA dalam memimpin, maka semakin tinggi pula performansi yang ditorehkan oleh Kepala RA. Sebaliknya, semakin tidak demokratis dalam memimpin, maka Kepala RA semakin sulit untuk memperoleh performansi terbaiknya.

\section{c) PengaruhKecerdasan Emosional $\left(X_{1}\right)$ dan Kepemimpinan Demokratis $\left(\mathrm{X}_{2}\right)$ terhadap Performansi Kepala RA (Y)}

Dari hasil perhitungan ANOVA diperoleh informasi tentang hasil perhitungan F sebesar 5,356 dan probabilitas (Sig.) 0,006 yang berarti lebih kecil dibandingkan dengan taraf signifikansi 0,05, sehingga dapat diambil keputusan bahwa Ho ditolak. Nilai F test sebesar 5,356 dan nilai sig. pada 0,006. Dengan berkonsultasi pada table $\mathrm{F}$ dengan $\mathrm{db}=\mathrm{m}$ lawan $\mathrm{N}-\mathrm{m}-1$ atau 2 lawan 132 ternyata harga Ftabel 5\%=3,06. Jadi 5,976>3,06 berarti signifikan.Oleh karena itu dapat 
QUALITY

Volume 5, Nomor 1, 2017: 170-189

disimpulkan bahwa variabel kecerdasan emosional $\left(\mathrm{X}_{1}\right)$ dan kepemimpinan demokratis $\left(\mathrm{X}_{2}\right)$ berpengaruh terhadap performansi Kepala RA (Y). Bila menggunakan $r$ tabel untuk $\mathrm{n}=150$ dan kesalahan $5 \%$ maka $r$ tabel $=0,159$ sedangkan untuk $r$ hitung adalah 0,274. Dari hasil perhitungan ternyata $r$ hitung lebih besar dari r tabel maka Ho diterima dan Ha ditolak.

Performasi adalah cara atau perilaku seseorang dalam melaksanakan tugasnya. Performasi setiap orang tentunya berbeda satu dengan yang lain, sebab setiap orang selalu memandang berbeda dalam setiap tugas yang diembannya. Yang terpenting dalam melaksankan sebuah tugas, adalah tugas tersebut dapat terselesaikan dengan cepat dan tepat.Oleh sebab itu, setiap pekerjaan harus selalu mempunyai standar operasional prosedur sehingga pekerjaan tersebut dapat dikerjakan dengan baik.

Kecerdasan emosi seseorang memiliki peran penting dalam mempengaruhi perasaaan, suasana hati maupun perilaku seseorang dalam bekerja. Seseorang yang memiliki kecerdasan emosional tentunya akan mampu mengelola emosinya sehingga dapat mengerjakan apa yang menjadi tanggung jawabnya dengan baik.Disisi lain, gaya kepemimpinan juga berpengaruh besar terhadap performasi seseorang dalam bekerja. Pemimpin yang mampu menciptakan iklim kerja yang nyaman, kondusif dan saling memotivasi tentunya akan mampu menjadikan bawahannya menjadi pribadi yang berkembang dalam kariernya.

Berdasarkan uraian dan hasil penelitian ini dapat dijelaskan, bahwa semakin tinggi kecerdasan emosional dan demokrastis Kepala RA dalam memimpin, maka semakin tinggi pula performansi yang ditorehkan oleh Kepala RA. Sebaliknya, semakin rendah kecerdasan emosional dan sikap tidak demokratis dalam memimpin, maka Kepala RA semakin sulit untuk memperoleh performansi terbaiknya.

\section{SIMPULAN}

Berdasar pada analsis data yang telah dilakukan diperoleh simpulan bahwa 1) kecerdasan emosional berpengaruh positif terhadap performansi kepala RA perempuan di Kabupaten Pati. Artinya setiap peningkatan kecerdasan emosional 
QUALITY

Volume 5, Nomor 1, 2017: 170-189

diikuti dengan peningkatan performansi kepala RA perempuan di Kabupaten Pati; 2) Kepemimpinan demokratis berpengaruh positif terhadap performansi kepala RA perempuan di Kabupaten Pati. Artinya setiap peningkatan kepemimpinan demokratis diikuti dengan peningkatan performansi kepala RA perempuan di Kabupaten Pati; 3) Kecerdasan emosional berpengaruh positif terhadap performansi kepala RAperempuan di Kabupaten Pati. Artinya setiap peningkatan kecerdasan emosional diikuti dengan peningkatan performansi kepala RA perempuan di Kabupaten Pati.

\section{DAFTAR PUSTAKA}

Agustian, A. G. (2005). Rahasia Sukses Membangun Kecerdasan Emosi dan Spiritual: ESQ The ESQ Way 165, Jakarta: ARGA.

Arikunto, S. (1996). Dasar - Dasar Evaluasi Pendidikan,Jakarta : Bumi Aksara.

Arikunto, S. (2002). Prosedur Penelitian Suatu Pendekatan Praktek, Jakarta: Rineka Cipta.

Danim, S. (2012). Kepemimpinan Pendidikan: Kepemimpinan Jenius (IQ+EQ) Etika, Perilaku Motivasional, dan Mitos, Bandung: Alfabeta.

Daryanto. (2011). Kepala Sekolah Sebagai Pemimpin Pembelajaran, Yogyakarta: Gava Media.

Direktorat Tenaga KependidikanDepartemen Pendidikan Nasional. (2008).Penilian Kinerja Kepala Sekolah, Jakarta: Direktorat Tenaga KependidikanDirektorat JenderalPeningkatan Mutu Pendidik Dan Tenaga KependidikanDepartemen Pendidikan Nasional.

Ghozali, I. (2005). Analisis Multivariate dengan Program SPSS, Semarang: Undip.

Goleman, D. (2004). Emotional Intelligence: Kecerdasan Emosional Mengeapa EI Lebih Penting Dari Pada IQ, Jakarta : PT. Gramedia.

Goleman, D. (2005). Working With Emotional Intelligence: Kecerdasan Emosi untuk Mencapai Puncak Prestasi, Jakarta: Gramedia Pustaka Utama.

Hadi, S. (2000). Metodologi Research, Yogyakarta : Andi Yogyakarta. 
QUALITY

Volume 5, Nomor 1, 2017: 170-189

Hude, M. D. (2006). Emosi : Penjelajahan Religio-Psikologis Tentang Emosi Manusia di Dalam Al-Qur'an, Jakarta: Erlangga.

Kartono, K. (1990). Pengantar Metodologi Riset Sosial , Bandung: Mondar Maju.

Masaong, A. K. dan Tilomi, A. A. (2011). Kepemimpinan Berbasis Multiple Intelligence: Sinergi Kecerdasan Intelektual dan Spiritual untuk Meraih Kesuksesan yang Gemilang), Bandung: Alfabeta.

Mulyasa,E. (2005).Menjadi Kepala Sekolah Profesional, Bandung: Remaja Rosda Karya.

Mulyasa,E. (2012). Manajemen Berbasis Sekolah, Bandung: Remaja Rosda Karya.

Prawirosentono, S.(1999). Manajemen Sumber Daya Manausia, Kebijakan Kinerja Karyawan, Yogyakarta: BPFE.

Salam, A. (2014). Manajemen Insani dalam Pendidikan, Yogyakarta: Pustaka Pelajar.

Santoso, G. (2005). Metode Penelitian Kuantitatif, Jakarta: Prestasi Pustaka Publisher.

Sondang, P. S.(2011). Teori dan Praktek Kepemimpinan, Jakarta: Rineka Cipta

Sudjana, N. (1999). Tuntunan Menyusun Karya Ilmiah, Bandung: Sinar Baru Algesindo.

Sugiyono. (2008).Metode Penelitian Pendidikan (Pendekatan Kuantitatif, Kualitatif, dan R\&D, Bandung: Alfa Beta.

Sukmadinata, N. S. (2009). Metode penelitian Pendidikan, Bandung: Remaja Rosdakarya.

Thoha, M. (1986). Perilaku Organisasi : Konsep Dasar dan Aplikasinya, Jakarta: Rajawali Press.

Widoyoko, E. P.(2015). Teknik Penyusunan Instrumen Penelitian, Yogyakarta: Pustaka Pelajar.

Widoyoko, S. E. P. (2015). Teknik Penyusunan Instrumen Penelitian, Yogyakarta: Pustaka Pelajar. 